\title{
On the Current Situation and Countermeasures of National Defense Education System Construction in Chinese Universities
}

\author{
Cheng-hu JIANG ${ }^{1, *}$, Jia-yi LI ${ }^{2}$ \\ ${ }^{1}$ Security Office, Nanjing University of Finance \& Economics, Nanjing, Jiangsu, China \\ ${ }^{2}$ School of Economics, Nanjing University of Finance \& Economics, Nanjing, Jiangsu, China \\ ${ }^{*}$ Corresponding author
}

\begin{abstract}
Keywords: Chinese Universities; National Defense Education; National Defense Discipline Construction.
\end{abstract}

\begin{abstract}
The national defense education in universities is an indispensable part of national defense construction. The discipline system of national defense education in Chinese universities has become increasingly mature. However, the pace of development of the national defense education in colleges and universities has always been lagging behind the pace of education reform in China. Facing some new challenges, such as military affairs innovation and information warfare, it still has a lot of problems against the socialist market economy background. This paper elaborates the status quo of the discipline construction of national defense education in universities in recent years and the problems to be solved urgently, and proposes a series of corresponding countermeasures for the current national defense education innovation and discipline construction.
\end{abstract}

\section{Introduction}

As an essential part of national defense construction, national defense education in universities has two characteristics: education and military. It is of great significance to the moral, intellectual, physical education, and even the whole quality cultivation process of college students. A comprehensive and systematic national defense education system can improve students' ideological and political quality, scientific and cultural quality, physical quality, and psychological quality, and is more conducive to fostering their awareness of teamwork and collectivism. College students are the national reserve military forces. Strengthening national defense education in colleges and universities is a fundamental project for the solidarity and prosperity of our country. Collectivism education is the direct theme of the national defense education in universities and patriotism education is the eternal topic. The top priority of national defense education in universities is to strengthen the awareness of national sovereignty, national interests and national security.

\section{Current Situation and Problems of National Defense Education System in Universities}

What is National Defense Education? National Defense Education (NDE) refers to social activities that exert purposeful, organized and planned influence on all citizens in order to safeguard national sovereignty, territorial integrity and security, resist foreign aggression, subversion and threats, thus to make citizens have certain national defense knowledge and skills, and form national defense awareness and feelings that meet the needs of the country. NDE in universities shoulders the great responsibility of educating talents and strengthening the country, and in recent years, colleges and universities have gradually comprehensively implemented the discipline of national defense and achieved certain results. However, generally speaking, the definition of national defense education practice is relatively narrow. The teaching content of military courses is limited to the basic theory of NDE, which lacks divergent thinking and cannot meet the current trend of internal and external environment in China. There is also a lack of normative teaching management. The problems are mainly reflected in the following aspects: 


\subsection{The teaching staff is not clear; the internal management system of universities is chaotic; the academic development of national defense education lacks discipline support}

The teaching staff is an important factor to improve the NDE level. At present, some colleges and universities in China have not established a fixed full-time teaching team and the school leaders pay little attention to the construction of teaching staff. There is a serious shortage of professional teachers. There are also major problems in the titles and qualifications of military full-time teachers. The internal preparation of colleges and universities is even more varied. Some universities treat NDE as a party education activity. Some set up specialized military teaching departments for NDE, and others invite military instructors outside to teach in school. The management system is unclear and the organizational structure is chaotic. It is difficult to advance the teaching task and to guarantee the teaching quality, so that less energy is devoted to NDE and military teaching research. To rapidly develop the discipline system of NDE, it requires a high-quality, high-quality teaching staff, with a high level of scientific and cultural knowledge, as well as solid military theories and the educational laws. Moreover, the progress in the discipline construction of NDE is slow, and its status has not yet been established. At present, the NDE has no place in the list of disciplines published by the Academic Degrees Committee of the State Council and the Ministry of Education. Therefore, for a long time, the majority of national defense educators have been faced with a situation without subject support. Teachers of NDE in colleges and universities generally lack a sense of belonging, and the space for academic development is not broad enough.

\subsection{National defense education lays more emphasis on theory than practice, and its teaching content lacks timeliness and international vision}

The common forms of NDE in domestic universities can be summed up in the following three types: students' military training, military theory teaching, and daily national defense education activities. The military theory courses aim to systematically teach college students the basic knowledge of China's national defense, military thought, strategic environment, military high technology, information warfare, doctrine education and training of the Chinese people's liberation army, light weapons shooting, military tactics and military topography and so on, which cover two major aspects of military theory and technical training. The teaching mode is usually traditional teaching by teachers, supplemented by online course system of internet in universities. Thanks to the diversification and flexibility of modern media, multimedia educational technology is usually adopted in classroom teaching, which integrates sound, text, images, video and other information. Compared with the past, the teaching is more vivid and intuitive, colorful and flexible, which effectively increases the amount of information in classroom teaching, enhances the attractiveness of lectures, thus achieving the purpose of improving the teaching effect. This innovation of the teaching method is worthy of recognition and further promotion. However, national defense theory teaching attaches importance not only to the "hard" skills of students such as national defense science and technology and weapons and equipment, but also to the indoctrination of "invisible", "soft" skills such as national spirit and fighting will, which need to be realized through colorful national defense education practices. Through these activities, they can make up for the deficiency of classroom teaching, meet college students' needs for military knowledge, and consolidate the development of national defense theory teaching. Furthermore, the construction of teaching materials is also a key link in the discipline construction of NDE. On the one hand, the contents of textbooks are short of timeliness. It is necessary to add the latest national defense research achievements and to eliminate contents which are outdated or inconsistent with today's development situation. On the other hand, the comparative military science should also be added. It is essential to appropriately introduce national defense measures of various countries in the world and the dynamics of foreign military development, pay attention to the international situation, properly learn from overseas NDE concepts and policies to broaden the international vision. 


\subsection{National defense education can't arouse students' interest in learning, and their national defense awareness is weak}

At present, universities and colleges all actively carry out NDE courses. However, the due function of NDE has not been effectively brought into play because teachers and students are not fully aware of the important role of NDE in students' personal growth and national defense construction. In general, there is a tendency of formalism and short-term behavior in NDE. In the process of national defense teaching, teachers' contents are too broad and arbitrary, so the effect and quality of NDE are stagnant in low level and superficial stage. College students pay little attention to NDE, and lack interests and patriotism with weak overall national defense awareness, which show their paralysis psychology in peacetime. Even some students narrowly think that NDE is only a matter of military or military colleges, and national defense construction is a task at the national level. The reason is that NDE in many colleges and universities only includes short-term centralized military training with obsolete training contents which are queue, field training, military gymnastics, and individual tactics training, etc. These dogmatic and rigid forms cannot be accepted by students, and also cannot adapt to the needs of high-tech warfare. In addition, the military officers are alienated from students and lack sufficient communication with each other in the military training. Students generally believe that military instructors are serious without any emotional communication. They have no concrete understanding of the real military life and military spirit. The comprehensive educational function of NDE is a kind of long-term benefit, and short-term centralized behavior also objectively makes it impossible for students to truly care about, support and participate in national defense construction. NDE should focus more on the "rationality" and "sensibility". It is necessary to not only pay attention to the cultivation of national defense awareness, but also regularly let students directly place themselves in national defense. Only by transforming the cognition of "knowing national defense" into the love for national defense can students truly support and participate in national defense construction.

\subsection{National defense education can't be well integrated with other disciplines}

The discipline of national defense is highly integrated and it comprehensively utilizes all the scientific achievements and wisdom of human creation. The special education in a single discipline is often adopted in current teaching to enable students to systematically recognize national defense, which is separated from the specific military theory, and is rarely involved in other disciplines. We should try to carry out interdisciplinary penetration of NDE in colleges and universities, and further integrate them from the perspectives of history, economics, sociology, psychology, philosophy, management and military science to seek more teaching approaches. Integrating the content of NDE into other disciplines requires teachers of different disciplines to clarify the military value in teaching according to the characteristics of the courses they teach, so as to deepen students' understanding of national defense, thus forming a comprehensive and wide-ranging national defense education model.

\section{Countermeasures of National Defense Education}

After years of practice and exploration and theoretical research and improvement in colleges and universities, NDE and its discipline construction have achieved certain results, and basically forming a set of relatively systematic and effective teaching ideas and specific methods, which have laid the foundation for the national defense education in colleges and universities. According to the current world situation, we should pay more attention to improving the effect of discipline education and promoting the overall development of students, so as to make NDE a kind of conscious behavior with leadership, planning and organization.

To further improve NDE in colleges and universities, accelerate its system construction and comprehensively improve the quality of students, the following countermeasures are put forward: 


\subsection{Focusing on updating educational concepts}

It is necessary to keep up with the trend of the times, seek new development with new ideas, and make all aspects of NDE in universities reflect distinctive characteristics of the times. Both teachers and students should fully realize the important role of NDE in quality education in colleges and universities. NDE is not only the content, but also an effective way to strengthen quality education. Therefore, we must try to get rid of the original rigid image of national defense education.

At the same time, comparative military science is an effective way of educational innovation. We should draw lessons from the NDE of universities in Western countries, and find out the successful experience to deepen the development of NDE in China. For example, the NDE in American colleges and universities is involved in various kinds of education, not only the propaganda and indoctrination of national defense knowledge, but also the organic combination of NDE and education of natural science and social science. It emphasizes the mutual penetration and coordinated development of all aspects, that is, not simply treating NDE as a simple military education, but as spiritual education centering on patriotism, including political education, situation education, legal education, military knowledge education, civil defense education, combat readiness education and so on. NDE in Japanese universities strengthens patriotism and national defense concepts of college students by implementing crisis education and strengthening civil-military relations, so as to enhance people's sense of national security.

\subsection{Emphasizing innovative educational methods}

NDE in colleges and universities should attach great importance not only to the education of students on national defense science and technology, and weapons and equipment, but also to their national spirit and fighting will. It has to further broaden the curriculum content system and increase the teaching content of "non-traditional security" such as social security, cultural security, information security, scientific and technological security, ecological security and economic security. In recent years, issues in non-traditional security fields, such as Sino-US trade war and Xinjiang violent and terrorist incidents, which are generally concerned by the society, should be actively introduced into the class, integrated into the teaching content of "internal security", to guide students to have a rational understanding of national defense, pay attention to national security and make contributions to the internal security of our country and social stability. At the same time, it is necessary to carry out activities such as military-civilian get-togethers, military athletics, and preferential treatment for families of servicemen and martyrs, so as to allow students to participate in military practice and guide them to have a perceptual understanding of national defense. Specialized agencies, special courses and activities should be set up to help students systematically understand national defense. The content of NDE should be incorporated into various disciplines education. And the organic combination of the two methods should be adopted to promote the improvement of effectiveness of NDE. Contemporary college students are active in thinking, innovative and strong in expression, and have the characteristics of modernity and reality. Therefore, in the teaching form, students' personalities and preferences should be considered. Teachers need to combine teaching with pleasure, such as integrating military movie appreciation into the classroom, organizing visits to military sites, archives, and memorials, and conducting patriotic speech competitions and debates. In terms of the teaching of national defense theory, the timeliness must be focused, that is, to closely combine the course with military dynamics at home and abroad, and the teaching content with hot issues. Teachers of national defense should closely follow the development and changes in the situation, and promptly update the teaching content most concerned by college students in the classroom. They can also allow students to make topical group discussions or speeches on national defense affairs to mobilize the enthusiasm of students for knowledge and make the teaching of national defense theory full of vigor and vitality. During the military training, while carrying out traditional compulsory projects, it is also necessary to actively integrate training programs with the characteristics of the times which are close to real life, such as the fire escape drills, anti-terrorism and anti-riot drills, etc., so as to enhance the practical significance and attractiveness of military training. 


\subsection{Strengthening teaching management and standardizing the teaching staff construction}

The key to strengthening NDE in universities and improving teaching quality is to build a full-time teaching staff with stable thoughts, appropriate quantity, reasonable structure and skilled business. Military teachers should not only be versed in the professional knowledge and skills, but also master the whole contents and theoretical basic knowledge of this discipline and have a broad understanding of related disciplines. NDE in universities has to focus on the construction of talent team with long-term and annual plans. First of all, a scientific and reasonable staffing plan must be formulated to supplement the teachers in the shortest time. Besides, it is very important to cultivate the existing teaching staff and constantly improve their educational level and practical work ability. In addition, the systems of demonstration, trial teaching and communication should be improved. And the teaching level of teachers needs to be increased by taking measures such as listening to each other, observing teaching, and holding teacher-student exchange meetings. Colleges and universities should actively carry out teaching evaluation and establish strict teaching inspection and evaluation system. It is necessary to formulate evaluation methods for teaching work in research rooms, teachers' teaching quality, students' assessment, and high-quality courses, etc., and organize and implement them regularly. Meanwhile, academic seminars and business learning meetings should be carried out. On the one hand, it can deepen the understanding of the content and form of national defense construction. On the other hand, it can also help teachers broaden their horizons and learn from each other, thus promoting the improvement of the teaching level. Teaching and scientific research have always been the two pillars of college work, and they are complementary to each other. Through scientific research activities, it is possible to organically combine national defense theory with teaching practice, which is conducive to improving teaching level and quality, enriching teaching content, broadening teaching ideas and promoting teaching reform. The national defense course will be developed to a higher and deeper level by improving the teaching mechanism, establishing the teaching system of national defense education, implementing the credit system and re-study system, and adhering to pedagogy and educational academic research system.

\subsection{Defining the purpose of students' national defense education and correcting their learning attitudes}

NDE is the key to training excellent talents. Its purpose is essentially the same as that of quality education. A college student who lacks the concept of national defense construction cannot be a useful talent for the modernization of the country. NDE aims to strengthen the national defense sense of students, increase their political awareness of safeguarding and building their motherland, and carry forward the patriotism and inspire the national spirit. In peacetime, the purpose of NDE in universities is not only limited to the national defense construction itself, but also can be transformed into a kind of spirit which can be instilled into the minds of students, into a great spiritual motivation for them to study hard to realize the strategic goal of the country. Military science covers disciplines such as history, society, politics, philosophy, geography and so on, which has a positive role in the construction and improvement of students' knowledge system structure. Through the study of military science, students can expand their knowledge and broaden their horizons. During the teaching process, teachers should consciously stimulate students' creativity in learning, break the conventional thinking pattern, and develop students' ability to find, analyze and solve problems. At the same time, the corresponding military training can help students set up correct attitude on hardship and happiness and improve their psychological quality. In military training, teachers should pay attention to students' ability to communicate and cooperate with others, help them constantly adjust their differences and integrate into the team. Contemporary college students have three kinds of attitudes towards national defense courses. They have a keen interest but their knowledge of national defense is almost blank; they are strongly sensitive to high-tech national defense and hot issues in the world, but unable to comprehensively and correctly analyze the development trend of world military and political situation; they have strong admiration for the armed forces of the military powers and strong patriotism, but lack enough confidence in the 
modernization process of our army. In this regard, teachers should encourage students more, analyze and explain the issues that students are interested in.

In short, the construction of national defense education in Chinese universities requires the full attention of relevant departments and the cooperation of teachers and students. The discipline system construction has gradually matured and improved. NDE in universities is a vital part of national defense construction, and it is an important historical task entrusted by the country to higher education in the new era.

\section{Acknowledgements}

Authors are grateful to the Brand Major Construction Project of University in Jiangsu (PPZY2015B103); Teaching Reform Project of Jiangsu (2017JSJG047); Project of Evaluation Committee of Higher Education Society in Jiangsu (Pgwyh07101); Teaching Reform Project of Nanjing University of Finance and Economics (JGZ1805).

\section{References}

[1] K., Li, Z.M., Zhang and H.B., Wen. Innovative Mode of National Defense Education in Non-military Universities in the View of "Overall National Security" [J]. Journal of Yangzhou University (Higher Education Study Edition), Vol. 19 (2), 2015, pp. 63-66.

[2] K., Li. National Defense Education in Chinese Universities: Basic Models, Problems and Countermeasures [J]. Journal of Wuhan University of Science and Technology (Social Science Edition), Vol. 15 (4), 2013, pp. 455-459.

[3] H., Zheng. National Defense Education Research in China's Regular Universities: Retrospect and Prospect - Based on Analyzing Conference Papers of National Defense Education Research in China's Regular Universities (1997-2009) [J]. Journal of Higher Education, Vol. 32 (1), 2011, pp. 86-90.

[4] J., Ma. The "Three Links" of National Defense Education in Local Universities [J]. National Defense, Vol. (7), 2006, pp. 10-11.

[5] Y.P., Li and H.J., Feng. On the Role of National Defense Education in Improving Students' Comprehensive Quality [J]. Popular Culture and Arts, Vol. (12), 2010, pp. 213-214.

[6] A.Q., Ma and M., Chen. The Significance, Status Quo and Countermeasures of College Students' National Defense Education [J]. Journal of Liaoning Academy of Governance, Vol. 11 (1), 2009, pp. 113-115.

[7] S.G., Xu. University Defense Education Urgently Needs to be Strengthened and Innovated [J]. China Higher Education Research, Vol. (1), 2003, pp. 82, 86.

[8] Y.M., Shi. Research on National Defense Education in Chinese Universities from the Perspective of Quality Education [D]. Central South University, 2006. 